\title{
Horses and Cattle Grazing on the Wyoming Red Desert, III
}

\author{
G.E. PLUMB, L.J. KRYSL, M.E. HUBBERT, M.A. SMITH, AND J.W. WAGGONER
}

\begin{abstract}
Vegetative cover losses due to trampling near watering sites in the summer and winter are compared for horses grazed alone, cattle grazed alone and horses and cattle grazed in combination. There were significant differences $(p<.05)$ found in the rates of total cover loss as a function of distance to water in both the summer and winter. Grasses sustained heavy trampling losses in all treatments in both seasons. Forbs sustained heavy losses in all treatments during summer. Shrub losses were moderate to low in all treatments during both seasons. Total cover loss was similar in all summer and winter treatments.
\end{abstract}

Water sources of cattle (Bos taurus) and horses (Equus caballus) on open range in the Red Desert of Wyoming have surrounding areas with heavy grazing or trampling use. Loss of forage due to trampling has long been recognized as a problem by livestock producers. Thomas (1960) suggested heavy trampling effects may be equal to, if not more important than, excessive grazing in reducing forage production. Several studies have examined the effects of trampling on rangeland vegetation (Packer 1953, Pegua 1970, Bryant et al. 1972, Laycock and Harniss 1974). None of these studies have investigated trampling losses by horses, or horses and cattle grazing in combination. The objective of this study was to determine rate of cover loss due to trampling near a water source for horses alone, cattle alone, and horses and cattle in combination under heavy grazing regimes.

Authors, at the time of the study, were research aides III, research associate Division of Animal Science, University of Wyoming; assistant professor, Division of Range Management, University of Wyoming; associate professor, Division of Animal Science, University of Wyoming, Laramic, 8207l.

Mr. Plumb is currently a graduate assistant, Department of Range and Wildlife Management, Box 4169, Texas Tech University, Lubbock, Texas 79409.

This research was conducted under contract AA851-CTO-31 between Bureau of Land Management and University of Wyoming.

Manuscript received July 19, 1982.

\section{Study Area and Methods}

The study was conducted in the Red Desert of Wyoming approximately $93 \mathrm{~km}$ northeast of Rock Springs, Wyo., in Sweetwater County. A semiarid climatic pattern prevails over the area. Three distinct vegetation types; sagebrush-grass, saltbrush, and greasewoodrabbit brush, cover most of the area. For a more complete description of the study area see Krysl et al. (1984).

The study sites were located on traditional summer or winter ranges of cattle and feral horses. Pastures were selected to be as similar as possible although some differences did ocur in species composition. Animal numbers and stocking rates for the summer study by treatment were: horses grazed alone, 12 horses and 1 colt (2.8 AU/ha); cattle grazed alone, 13 cattle and 8 calves $(2.4$ $\mathrm{AU} / \mathrm{ha}$ ); horses and cattle grazing in combination, 11 horses, 2 colts, 13 cattle and 8 calves ( $2.5 \mathrm{AU} / \mathrm{ha})$. Animal numbers and stocking rates for the winter study by treatment were; horses grazed alone, 14 horses and 2 colts $(3.3 \mathrm{AU} / \mathrm{ha})$; cattle grazed alone, 12 cattle $(2.3 \mathrm{AU} /$ ha $)$; horses and cattle grazed in combination, 12 cattle, 14 horses and 1 colt $(2.8 \mathrm{AU} / \mathrm{ha})$. Detailed information on grazing treatments is found in Krysl et al. (1984).

One, 1,300 -liter, $2 \mathrm{~m} \times .7 \mathrm{~m} \times .6 \mathrm{~m}$, water trough was used as the water source in each treatment. Each trough was located in an area visually determined to be as vegetatively homogeneous as possible. Ice in each trough was broken and or removed once a day when necessary. For the purposes of this study, trampling loss refers to that portion of the forage which, through the trampling action of horses or cattle, has been removed or damaged so that it will not be available for consumption (Quinn and Hervey 1970). Heavy trampling losses are considered greater than $60 \%$, moderate losses are $59-30 \%$, and light losses less than $30 \%$.

Trampling losses were determined using an adapted form of the 
line interception method (Canfield 1941). Five, 61-m line transects radiated out from a post behind each trough. Transects were permanent and vegetative cover increments were measured to the nearest estimated $.6 \mathrm{~cm}$.

In most trampling studies the effects of grazing and trampling are confounded because the effects of grazing are not easily separated from the effects of trampling (Reynolds and Packer 1962). However, the removal of vegetation in the 61-m area around each water source of this study was considered to be an effect of trampling only. It was observed that in both summer and winter cattle and horses generally went directly to water when they arrived within 100-150 m of the water source. Quinn and Hervey (1970) also observed that steers failed to stop and graze when travelling to water.

Vegetation was divided into three classes: forbs, grasses, and shrubs. The initial measurement and following measurements were designated by $T_{0}, T_{1}, T_{2}$, and $T_{3}$, respectively. Measurement $T_{0}$ was completed before the water trough was placed in each treatment. Subsequent measurements were made at 10- to 14-day intervals. During the winter study, $T_{2}$ was not obtained due to snow cover.

Total cover loss by treatment and plant type was determined from the difference in total centimeters of cover between $T_{0}$ and $T_{3}$. Total cover loss as a function of distance from water was determined by dividing the transects into $15-\mathrm{m}$ increments and comparing each increment from $T_{0}$ to $T_{3}$. An approximate variance was calculated for each $T_{3} / T_{0}$ ratio (Cochran 1975). A standard $t$-test was conducted comparing the variance of two selected ratios. Significance is reported at $p<.05$. Observations of inter- and intra-specific interactions between horses and cattle around the water source were made throughout the study.

\section{Results and Discussion}

There were significant differences $(p<.05)$ in the amount of total cover loss due to trampling related to distance from water in all treatments for both the summer and winter periods (Table 1). For Table 1 . Percent total cover loss in $15 \mathrm{~m}$ increments, $T_{0}-T_{3}$, summer and
winter study periods.

\begin{tabular}{lccccc}
\hline \hline \multirow{2}{*}{$\begin{array}{l}\text { Grazing } \\
\text { treatment }\end{array}$} & & \multicolumn{4}{c}{ Distance from water source } \\
\cline { 2 - 6 } & & $0-15 \mathrm{~m}$ & $16-30 \mathrm{~m}$ & $31-45 \mathrm{~m}$ & $46-61 \mathrm{~m}$ \\
\hline Cattle & $\mathrm{S} !$ & $74_{\mathrm{a}}{ }^{2}$ & $32_{\mathrm{b}}$ & $26_{\mathrm{b}}$ & $31_{\mathrm{b}}$ \\
alone & $\mathrm{W}$ & $63_{\mathrm{a}}$ & $44_{\mathrm{b}}$ & $47_{\mathrm{b}}$ & $44_{\mathrm{b}}$ \\
Horses & $\mathrm{S}$ & $54_{\mathrm{a}}$ & $60_{\mathrm{a}}$ & $50_{\mathrm{a}}$ & $44_{\mathrm{a}}$ \\
alone & $\mathrm{W}$ & $57_{\mathrm{a}}$ & $39_{\mathrm{b}}$ & $27_{\mathrm{b}}$ & $21_{\mathrm{b}}$ \\
Horses \& & $\mathrm{S}$ & $60_{\mathrm{a}}$ & $76_{\mathrm{a}}$ & $34_{\mathrm{b}}$ & $7 \mathrm{c}$ \\
Cattle & $\mathrm{W}$ & $65_{\mathrm{a}}$ & $70_{\mathrm{a}}$ & $35_{\mathrm{b}}$ & $37_{\mathrm{b}}$ \\
together & & & & & \\
\hline
\end{tabular}

I $\mathrm{S}=$ summer, $\mathrm{W}=$ winter

2 Values with unlike subscripts in rows are significantly different $(p<.05)$.

both summer and winter studies, heavy trampling by cattle grazed alone occurred within the $0-15 \mathrm{~m}$ increment. Losses within the 16-61 $\mathrm{m}$ increment were moderate and similar over the entire distance for both study periods. We believe the different levels of trampling losses are due to the behavior of cattle around the water source. Cattle generally travelled to water 3 or 4 times a day during summer and only 1 or 2 times each day during winter. After watering during summer, cattle usually bedded close to water for several hours. During winter they usually stayed close to water but remained standing. No grazing was observed during these periods. Sneva et al. (1973) indicated cattle with easy access to water generally drank twice a day and stayed close to water 2-3 hours following drinking.

The heaviest trampling losses within the $0-15 \mathrm{~m}$ increments were a result of cattle remaining close to the water source following drinking. Packer (1953) and Quinn and Hervey (1970) reported increased use of an area resulted in greater vegetation loss due to rampling. Moderate losses within the $16-61-\mathrm{m}$ area are concluded to be a result of failure of cattle to stop when proceeding to and leaving water.

During summer in the treatment containing only horses, trampling losses were moderate and similar over the entire $61-\mathrm{m}$ distance. However, during winter significantly greater losses occurred in the first 15-m increment with moderate to low losses within the 16-61-m increment. During summer horses came to water 5-7 times daily, remained briefly, and left as group immediately upon finishing d rinking. It should be noted that not all horses drank each time they came to water, but all did come to water as a group. During summer the $61-\mathrm{m}$ area around the trough received little use when total amount of time per day spent at the trough is considered. Less use could account for the lower rate of trampling losses.

During winter horses came to water 3 or 4 times a day as a group. The water source was sometimes iced over and the herd would remain close to the water source while one or two horses attempted to break the ice by hoof action. As would be expected, an increased amount of time spent in the $0-15 \mathrm{~m}$ increment, in an attempt to get water, increased trampling losses. Moderate to low vegetation loss in the 16-61 m increment was thought to be a result of horses proceeding to and leaving water without stopping.

The summer and winter treatments of horses and cattle grazed together showed very similar trends although actual amounts of loss differed. The increment of heavy trampling was twice as large as found for cattle during both study periods. Moderate losses occurred in the 31-61 m increment during both study periods except in summer in the 45-61 m increment, losses were very low.

The increase in area of heaviest trampling indicates possible effects of a horse-cattle interaction in close proximity to the water source. Horses coming to water occasionally encountered cattle at the trough. When this occurred several dominant horses would make threatening movements such as biting and kicking, similar to those described by Eibl-Eibesfeldt (1975), which prompted the cattle to disperse from the trough. When the horses had finished watering and left the area the cattle usually re-established themselves closer to the trough. When cattle and feral horses concentrate on the same water source in a free-roaming situation, aggressive behavior of horses towards cattle has been observed (Miller 1980).

This interaction between horses and cattle may cause heavier use of the entire 0-30 m increment and thus result in heavy trampling. Moderate to low losses due to trampling were sustained in the 31-61 m increment and were a result of animals failing to stop when travelling to and from water.

All treatments sustained increased total trampling losses over all increments and plant classes from $T_{0}$ to $T_{3}$. Total vegetative cover losses were moderate and very similar in all treatments during both study periods with one exception. Total cover loss was lower during winter where horses were grazed alone (Table 2).

Table 2. Percent load loss in 0-61 $\mathrm{m}$ increment, $T_{0}-T_{3}$, for summer and winter study periods.

\begin{tabular}{lcc}
\hline \hline Grazing treatment & Summer & Winter \\
\hline Cattle alone & $46_{\mathrm{a}}{ }^{1}$ & $48_{\mathrm{a}}$ \\
Horses alone & $46_{\mathrm{a}}$ & $32_{\mathrm{b}}$ \\
Horses \& Cattle together & $43_{\mathrm{a}}$ & $45_{\mathrm{a}}$ \\
\hline
\end{tabular}

\footnotetext{
1 Values with unlike subscripts in columns are significantly different $(p<.05)$.
}

It is generally accepted that horses consume snow to supplement their water requirements. This activity was observed for both horses and cattle. Snow consumption likely accounts for fewer trips made each day to water by both horses and cattle during winter. Since the water source was used less in winter, lower rates of total trampling losses caused by horses over the entire 0-61 m increment could be expected. Total trampling losses caused by 
horses and cattle grazed in common were the same $(p<.05)$ from summer to winter. Since total trampling losses from horses grazed alone dropped, the main trampling effect in the winter treatment where horses and cattle grazed together appears to be due mainly to cattle.

Although some differences in vegetal composition occurred between treatments in both seasons, mean values of initial percent cover by forage classes were calculated to give perspective to resulting cover losses (Table 3 ). Trampling losses of forbs during summer were very heavy (Table 3 ). Forbs were not a major diet

Table 3. Initial percent cover and percent loss by plant class in 0-61 $\mathrm{m}$ increment, $T_{0}-T_{3}$, for summer and winter study periods.

\begin{tabular}{lccccc}
\hline \hline & & \multicolumn{4}{c}{ Grazing treatment } \\
\cline { 3 - 6 } Forage & Season & $\begin{array}{l}\text { Initial } \\
\text { cover }\end{array}$ & $\begin{array}{l}\text { Cattle } \\
\text { alone }\end{array}$ & $\begin{array}{l}\text { Horse } \\
\text { alone }\end{array}$ & $\begin{array}{c}\text { Horse \& Cat- } \\
\text { tle together }\end{array}$ \\
\hline Forb & $\mathrm{S}^{1}$ & 20 & $92_{\mathrm{a}}$ & $91_{\mathrm{a}}$ & $95_{\mathrm{a}}$ \\
Grass & $\mathrm{S}$ & 17 & $80_{\mathrm{a}}$ & $9 \mathrm{a}_{\mathrm{a}}$ & $89_{\mathrm{a}}$ \\
& $\mathrm{W}$ & 13 & $70_{\mathrm{a}}$ & $85_{\mathrm{a}}$ & $61_{\mathrm{a}}$ \\
Shrub & $\mathrm{S}$ & 63 & $0 \mathrm{a}$ & $17 \mathrm{~b}$ & $31_{\mathrm{c}}$ \\
& $\mathrm{W}$ & 87 & $42_{\mathrm{a}}$ & $18 \mathrm{a}$ & $42_{\mathrm{a}}$ \\
\hline
\end{tabular}

I $S=$ summer, $W=$ winter

2 Values with unlike subscripts in rows are significantly different $(p<.05)$.

component for horses; however, they made up $9 \%$ of the cattle diet during summer (Krysl 1984). By mid June to early July forbs were drying out and were extremely susceptible to trampling damage in all three stocking treatments. Forbs were rare during winter and were not measured.

Grasses sustained heavy trampling losses in all treatments during both summer and winter (Table 3). Dominant grass species were mature by mid June to early July. Quinn and Hervey (1970) found needleandthread more likely to be trampled in July when seedheads were in various stages of maturity. Losses of grasses were generally lower during winter than during summer. Since animals came to water less during winter than summer, trampling damage decreased as expected.

Trampling losses of shrubs were the lowest of the various plant classes and different between treatments in the summer. Winter losses were similar for cattle grazed alone and in combination with horses, and lower for horses grazed alone (Table 3). The minimal loss of shrubs during summer when cattle grazed alone was thought to be due to avoidance of shrubs by cattle. By early winter some species of shrubs had lost all foliage. During winter, cattle grazed alone trampled shrubs with greater frequency than that observed during summer resulting in moderate trampling losses. Snow cover may have resulted in increased trampling of low shrubs. Horses grazed alone during summer and winter caused light losses of shrubs due to trampling. The horses avoided medium to large shrubs but when excited sometimes caused damage.

During summer, when horses and cattle grazed in common, moderate shrub loss was sustained but losses during winter were slightly higher. The increase in shrub losses during summer under common use, as compared to either horses or cattle grazed alone, were thought to be due to interaction between horses and cattle in the watering area. Both cattle and horses tended to damage shrubs when excited. During winter, when horses and cattle grazed in common, moderate shrub loss was sustained and losses were the same as where cattle grazed alone. This indicates the main trampling effect under common grazing was due to cattle.

\section{Conclusions}

Water sources on the open range in the Red Desert are sparse and much larger in size than those used in this study. Heavy concentrations of feral horses at water holes are common throughout summer months. Miller (1980) indicated that it is common to find 50 to 100 cattle at a single water hole in the Red Desert during summer. Since grasses and forbs sustain the heaviest trampling damage, ranchers might expect to lose a valuable portion of forage production adjacent to water sources. If horses and cattle use the same water sources a large area of heavy trampling of forage should be expected. Under such conditions, cattle and horses will have to travel further from water for feed. Squires (1978) stated that liveweight gain, and food and water intake were drastically affected when animals walked long distances for either grazing or water. According to Stephens et al. (1980), heavy trampling in sagebrush-grass types encourages microhabitat conditions favorable for succession of sagebrush rather than perennial grasses. Although precise amounts of trampling damage cannot be predicted under open range conditions, results similar to these might be expected to be found on a larger scale. Effects of winter trampling under free roaming conditions may be different because water sources are often frozen and thus not used for extended periods of time.

\section{Literature Cited}

Bryant, H.T., R.E. Blaser, and J.R. Peterson. 1972. Effect of trampling by cattle on bluegrass yields and soil compaction on a meadowville loam. Agron. J. 64:331-34.

Bureau of Land Management. 1978a. Rock Springs Sandy Grazing Environmental Statement. USDI, BLM Rock Springs District, Wyoming.

Bureau of Land Management. 1978b. Seven Lakes Grazing Environmental Statement. USDI, BLM Rawlins District, Wyoming.

Canfield, R.H. 1941. Application of the line-interception method in sampling range vegetation. J. Forestry. 39:338-394.

Cochran, R.S. 1975. Sampling notes. Stat. Lab. 2014, Univ. of Wyoming.

Eibl-Eibesfeldt, 1. 1975. Ethology, The Biology of Behavior. Holt, Rinehart, and Winston, Inc.

Krysl, L.J., M.E. Hubbert, B.F. Sowell, G.E. Plumb, T.K. Jewett, M.A. Smith, and J.W. Waggoner. 1984. Horses and cattle grazing in the Wyoming Red Desert, I. Food habits and dietary overlap. J. Range Manage. (In press).

Laycock, W.A., and R.O. Harniss. 1974. Trampling damage on a native forb-grass range grazed by sheep and cattle. In: Grassland Utilization, Intl. Grassland Proceedings. 12:349-54.

Miller, R. 1980. The ecology of feral horses in Wyoming's Red Desert. Ph.D. Diss. Univ. of Wyoming. Laramie.

Packer, P.E. 1953. Effects of trampling disturbance on watershed condition, runoff and erosion. J. Forestry. 51:28-31.

Pegua, R.E. 1970. Effect of reindeer trampling and grazing on lichens. J. Range Manage. 23:95-97.

Quinn, J.A., and D.F. Hervey. 1970. Trampling losses and travel by cattle on sandhills range. J. Range Manage. 23:50-54.

Reynolds, H.G., and P.E. Packer. 1962. Effects of trampling on soil and vegetation. p. 116-123. In: Range Research Methods A Symposium, USDA Misc. Publication No. 940.

Sneva, F.A., L.R. Rittenhouse, and L. Foster. 1973. Stock water restriction and trailing effects on animal gain, water drunk, and mineral consumption. p. 34-48. In: Water-Animal Relations Proceedings (Ed. H.F. Mayland), Water-Animal Relations Committee, Kimberly, Ida.

Squires, V.R. 1978. Distance trailed to water and livestock response. p. 431-434. In: 1st Int. Rangeland Congress. (Ed. D.N. Hyder), Denver, Colo. USA.

Stephens, J.L., R.E. Eckert, Jr., and F.F. Peterson. 1980. Effects of disturbance by natural and simulated cattle trampling on seedling emergence from different soil surface types. USDI Final Report, Univ. NevadaReno, Project 680.

Thomas, A.S. 1960. The trampling animal. Brit. Grassland Sci. J. 16:89-93. 